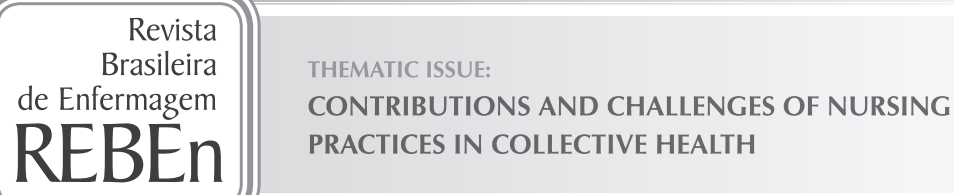

\title{
Social support of people with HIV/AIDS: the Social Determinants of Health Model
}

Suporte social de pessoas com HIVIAids: Modelo da Determinação Social da Saúde Soporte social de personas con VIH/SIDA: Modelo de la Determinación Social de la Salud

\author{
Vanessa da Frota Santos', Samyla Citó Pedrosa', Priscila de Souza Aquino', \\ Ivana Cristina Vieira de Lima', Gilmara Holanda da Cunha', Marli Teresinha Gimeniz Galvão' \\ ' Universidade Federal do Ceará, Department of Nursing. Fortaleza, Ceará, Brazil.
}

How to cite this article:

Santos VF, Pedrosa SC, Aquino PS, Lima ICV, Cunha GH, Galvão MTG. Social support of people with HIV/AIDS: the Social Determinants of Health Model. Rev. Bras. Enferm. [Internet]. 2018;71(Suppl 1):625-30. [Thematic Edition: Contributions and challenges of nursing practices in collective health]. DOI: http://dx.doi.org/10.1590/0034-7167-2017-0346

Submission: 05-15-2017 Approval: 11-11-2017

\begin{abstract}
Objective: To analyze the social support of people with HIV/AIDS from the perspective of the Social Determinants of Health Model. Method: This was a cross-sectional study conducted in 2015 in an infectious disease outpatient clinic. The sample was made up of 116 people with HIV/AIDS. The data was collected through interviews, using a sociodemographic form and a social support scale. The data was analyzed using descriptive statistics, and Student's t-tests and Mann-Whitney tests were performed to determine the association between social support and the social determinants of health. Results: Total social support was satisfactory, emotional support was influenced by smoking $(p=0.0432)$ and instrumental support, by the number of people in the household $(p=0.0003)$. The main source of instrumental and emotional support was relatives living outside the household, corresponding to $66.7 \%$ and $56.1 \%$, respectively. Conclusion: It was found that smokers havelower emotional support and people living alone received less instrumental support.
\end{abstract}

Descriptors: HIV; Acquired Immunodeficiency Syndrome; Social Support; Social Determinants of Health; Public Health.

\section{RESUMO}

Objetivo: analisar o suporte social de pessoas com HIV/Aids, na perspectiva do Modelo da Determinação Social da Saúde. Método: estudo transversal, realizado em 2015, em um ambulatório de infectologia. A amostra constituiu-se de 116 pessoas com HIV/Aids. A coleta de dados ocorreu mediante entrevista, utilizando-se o formulário sociodemográfico e a escala de suporte social. Os dados foram analisados por estatística descritiva, e realizaram-se os Testes T de Student e Mann-Whitney para verificar a associação entre o suporte social e os determinantes sociais de saúde. Resultados: o suporte social total foi satisfatório, o suporte emocional foi influenciado pelo uso de tabaco $(p=0,0432)$ e o instrumental, pelo número de pessoas no domicílio $(p=0,0003)$. A principal fonte de apoio do suporte instrumental e emocional foram os familiares externos ao ambiente doméstico representando $66,7 \%$ e 56,1\%, respectivamente. Conclusão: evidenciou-se que fumantes apresentam menor suporte emocional e que pessoas que residem sozinhas recebem menor suporte instrumental.

Descritores: HIV; Síndrome de Imunodeficiência Adquirida; Apoio Social; Determinantes Sociais da Saúde; Saúde Pública.

\section{RESUMEN}

Objetivo: Analizar el soporte social de personas con VIH/SIDA en la perspectiva del Modelo de la Determinación Social de la Salud. Método: Estudio transversal realizado en 2015 en un servicio de Infectología. Muestra integrada por 116 personas con VIH/SIDA. Datos recolectados mediante entrevista, utilizándose formulario sociodemográfico y escala de soporte social. Los datos se analizaron por estadística descriptiva. Se realizaron los tests T de Student y Mann-Whitney para verificar la asociación entre el soporte social y los determinantes sociales de salud. Resultados: El soporte social total fue satisfactorio, el soporte emocional resultó influido por consumo de tabaco $(p=0,0432)$, y el instrumental, por cantidad 
de personas en el domicilio $(p=0,0003)$. La principal fuente de apoyo del soporte instrumental y emocional fueron los familiares externos al ámbito doméstico, representando $66,7 \%$ y 56,1\%, respectivamente. Conclusión: Se evidenció que los fumadores presentan menor soporte emocional, y aquellos que viven solos reciben menor soporte instrumental.

Descriptores: VIH; Síndrome de Inmunodeficiencia Adquirida; Apoyo Social; Determinantes Sociales de la Salud; Salud Pública.

\section{CORRESPONDING AUTHOR}

\section{INTRODUCTION}

AIDS is a national health problem due to its high incidence. From 1980 until June 2016, 842,710 cases of AIDS were reported in Brazil, with $15.1 \%$ of them from the Northeast region $^{(1)}$. With the advent of the antiretroviral therapy (ART), there has been an increase in the life expectancy of people living with HIV/AIDS (PLWHA), thereby considerably reducing morbidity and mortality in this population ${ }^{(2)}$.

However, due to the history of the epidemiological profile of the disease, infection by HIV is strongly marked by stigma, prejudice and rejection by society, which can lead to social and family isolation ${ }^{(3)}$, and consequent undermining of social networks and health monitoring ${ }^{(4)}$. For PLWHA, the absence of social support has been associated with negative effects on psychological and physical well-being, such as episodes of depression, lower self-esteem, increased transmission of the virus, and progression to the final stage of the disease ${ }^{(5)}$.

Social support consists of material and psychological resources to which people have access through social networks $^{(6)}$. It is subdivided according to two factors: emotional social support which involves being listened to, attention, information, esteem, company and emotional support; and instrumental which represents support in operational matters related to treatment or health care and in practical day-to-day activities, in addition to material and/or financial help ${ }^{(7)}$.

Social support is a dimension of the Social Determinants of Health (SDH), defined as a set of social, economic, cultural, psychological, ethnic/racial and behavioral factors that influence health. The main SDH analysis model is from Dahlgren and Whitehead, which is arranged in five concentric layers, ranging from individual determinants (inherent to the person and not modifiable) to macrodeterminants (made up of economic, cultural and environmental conditions) ${ }^{(8)}$. Social support is found in the third layer of this model, which refers to the influence of social networks. This model has already been used to assess the quality of life of men with AIDS, where it was noted that the perception of quality life was higher among patients who lived with partners, which can be related to the social support received from them ${ }^{(9)}$.

Given the effects of social support in coping with the disease and the quality of life of PLWHA, it is essential to evaluate social support based on a model that takes into consideration the multiple dimensions of the health and disease process, in order to provide input for health professionals to identify and coordinate support networks that facilitate health care. In this context, the present study sought to analyze the social support of people living with HIV/AIDS from the perspective of the Social Determinants of Health Model (SDHM).

\section{METHOD}

\section{Ethical aspects}

The study met all the requirements for research with human beings and complied with the precepts of Resolution 466/12 of the National Health Council. It was approved by the Research Ethics Committee of the Walter Cantídio Teaching Hospital of the University of Ceará and received a Certificate of Presentation for Ethical Consideration (CAAE). All the patients signed a free and informed consent form.

\section{Type of study}

This was a cross-sectional study conducted from May to November 2015 in the infectious disease outpatient clinic of a public health service in Fortaleza, Ceará, Brazil.

\section{Sample selection}

The study sample was made up of 116 patients, selected by convenience, based on the following inclusion criteria: individuals aged 18 years or older, who had been receiving antiretroviral therapy for at least six months. The exclusion criteria were: suffering from a mental illness, identified through the consulting of medical records, in view of the fact that inaccurate information could possibly be supplied; pregnancy; people confined in prisons or police stations or those living in shelters.

\section{Data collection and instruments}

The data was collected in a place reserved for interviews, which lasted an average of 60 minutes, using a sociodemographic characterization form and the Social Support Scale for People Living with HIV/AIDS.

The content of the sociodemographic characterization form was validated in the PLWHA population ${ }^{(9)}$ and was adapted for this study, in accordance with the layers of the SDHM: layer 1- (individual determinants) sex, age group and color; layer 2(proximal determinants) sexual orientation, physical exercise, use of alcohol, use of tobacco and use of drugs; layer 3- (influence of social networks) marital status, children, number people in the household and religion; and layer 4- (intermediate determinants) household income, years of education and employment status.

The Social Support Scale for People Living with HIV/AIDS was validated for Brazil ${ }^{(10)}$ and was comprised of 22 items, divided according to two factors: emotional (10 items) and instrumental (12 items). To assess the results, an arithmetic mean was calculated for the items corresponding to each factor, where the higher the value the greater the satisfaction in relation to the support. Social support was considered satisfactory 
when the patients obtained a mean higher than three ${ }^{(11)}$. In relation to total social support, it was the sum of emotional and instrumental support.

\section{Statistical analysis}

Means, standard deviations and absolute and relative frequencies were used for the statistical analysis. The association between the means for social support and SDH was determined through the Student's t-test for independent variables and the non-parametric Mann-Whitney test. The association between categorical variables was determined through the chi-square test for independent variables. In all cases, the established significance level was $0.05(5 \%)$, where a $\mathrm{p}$-value $<0.05$ was considered statistically significant. The $\mathrm{R}^{\circledast}$ software, version 3.2.3 for Windows ${ }^{\circledast}$, was used for performing the analyses.

\section{RESULTS}

Table 1 presents the sociodemographic categorization of PLWHA according to the SHDM. In relation to the individual determinants, $55.2 \%$ were women, with a mean age of $39.6 \pm 8.5$ years, particularly from the age group of 18 to 40 years $(59.5 \%)$, and brown skin color (58.6\%). With respect to layer $2,73.3 \%$ were heterosexual, $50.9 \%$ did not exercise regularly, $54.3 \%$ did not consume alcohol, $81.9 \%$ did not smoke, and $94.8 \%$ did not use illicit drugs. As for layer 3, $44.8 \%$ were married, $56.9 \%$ did not have children, $81.9 \%$ lived with more than two people in the household, and $90.6 \%$ professed a religion. Among the intermediate determinants, $66.4 \%$ had household incomes lower than three minimum wages, $66.4 \%$ had more than 9 years of education, and $52.6 \%$ had an active employment status.

When associating the variables related to the SHDM layers with the data from the social support scale, it was noted that total social support was satisfactory, and was influenced by the proximal determinant of use of tobacco $(p=0.015)$, i.e., smokers received less total social support (Table 1).
Table 1 - Total social support of people living with HIV/AIDS, according to the Social Determinants of Health Model, Fortaleza, Ceará, Brazil, 2015

\begin{tabular}{|c|c|c|c|c|}
\hline \multirow{2}{*}{$\begin{array}{l}\text { Layers of the Social } \\
\text { Determinants of Health Model }\end{array}$} & \multicolumn{2}{|c|}{$\begin{array}{c}\text { Total Social Support } \\
\text { Satisfactory Unsatisfactory }\end{array}$} & \multirow[t]{2}{*}{$\begin{array}{l}\text { Total } \\
\text { n (\%) }\end{array}$} & \multirow{2}{*}{$\underset{\text { value }^{p}}{p}$} \\
\hline & $\mathrm{n}(\%)$ & $n(\%)$ & & \\
\hline \multicolumn{5}{|l|}{ 1. Individual determinants } \\
\hline \multicolumn{5}{|l|}{ Sex } \\
\hline Male & $35(30.1)$ & $17(14.7)$ & $52(44.8)$ & 0.4800 \\
\hline Female & $48(41.4)$ & $16(13.8)$ & $64(55.2)$ & \\
\hline \multicolumn{5}{|l|}{ Age group (in years) } \\
\hline$\leq 40$ & $51(44.0)$ & $18(15.5)$ & $69(59.5)$ & 0.6359 \\
\hline$>40$ & $32(27.5)$ & $15(12.9)$ & $47(40.5)$ & \\
\hline \multicolumn{5}{|l|}{ Skin color } \\
\hline Brown & $52(44.8)$ & $16(13.8)$ & $68(58.6)$ & 0.2346 \\
\hline Other & $31(26.7)$ & $17(14.7)$ & $48(41.4)$ & \\
\hline \multicolumn{5}{|l|}{ 2. Proximal determinants } \\
\hline \multicolumn{5}{|l|}{ Sexual orientation } \\
\hline Heterosexual & $60(51.7)$ & $25(21.6)$ & $85(73.3)$ & 0.8821 \\
\hline Homosexual / Bisexual & $23(19.8)$ & $8(6.9)$ & $31(26.7)$ & \\
\hline \multicolumn{5}{|l|}{ Physical exercise } \\
\hline Yes & $45(38.8)$ & $12(10.3)$ & $57(49.1)$ & 0.1261 \\
\hline No & $38(32.8)$ & $21(18.1)$ & $59(50.9)$ & \\
\hline \multicolumn{5}{|l|}{ Use of alcohol } \\
\hline Yes & $41(35.3)$ & $12(10.4)$ & $53(45.7)$ & 0.2869 \\
\hline No & $42(36.2)$ & $21(18.1)$ & $63(54.3)$ & \\
\hline \multicolumn{5}{|l|}{ Use of tobacco } \\
\hline Yes & $10(8.6)$ & $11(9.5)$ & $21(18.1)$ & 0.0155 \\
\hline No & $73(62.9)$ & $22(19.0)$ & $95(81.9)$ & \\
\hline \multicolumn{5}{|l|}{ Use of illicit drugs } \\
\hline Yes & $3(2.6)$ & $3(2.6)$ & $6(5.2)$ & 0.4611 \\
\hline No & $80(69.0)$ & $30(25.8)$ & $110(94.8)$ & \\
\hline \multicolumn{5}{|l|}{ 3. Influence of social networks } \\
\hline \multicolumn{5}{|l|}{ Marital Status } \\
\hline Single & $32(27.6)$ & $13(11.2)$ & $45(38.8)$ & 0.9749 \\
\hline Married & $37(31.9)$ & $15(12.9)$ & $52(44.8)$ & \\
\hline Other & $14(12.1)$ & $5(4.3)$ & $19(16.4)$ & \\
\hline \multicolumn{5}{|l|}{ Children } \\
\hline Yes & $34(29.3)$ & $16(13.8)$ & $50(43.1)$ & 0.596 \\
\hline No & $49(42.2)$ & $17(14.7)$ & $66(56.9)$ & \\
\hline \multicolumn{5}{|l|}{ Number of people in the household } \\
\hline 1 & $13(11.2)$ & $8(6.9)$ & $21(18.1)$ & 0.414 \\
\hline$\geq 2$ & $70(60.3)$ & $25(21.6)$ & 95 (81.9) & \\
\hline \multicolumn{5}{|l|}{ Religion } \\
\hline Professes & $75(64.7)$ & $30(25.9)$ & $105(90.6)$ & 1.0000 \\
\hline Does not profess & $8(6.8)$ & $3(2.6)$ & $11(9.4)$ & \\
\hline \multicolumn{5}{|l|}{ 4. Intermediate determinants } \\
\hline \multicolumn{5}{|l|}{ Household income (Minimum wage) } \\
\hline$<3$ & $55(47.4)$ & $22(19.0)$ & $77(66.4)$ & 1.0000 \\
\hline$\geq 3$ & $28(24.1)$ & $11(9.5)$ & 39 (33.6) & \\
\hline Years of education & & & & \\
\hline$\leq 9$ & $29(25.0)$ & $10(8.6)$ & $39(33.6)$ & 0.7955 \\
\hline$>9$ & $54(46.6)$ & $23(19.8)$ & $77(66.4)$ & \\
\hline Employment status & & & & \\
\hline Active & $44(37.9)$ & $17(14.7)$ & $61(52.6)$ & 1.0000 \\
\hline Inactive & $39(33.6)$ & $16(13.8)$ & $55(47.4)$ & \\
\hline
\end{tabular}

Note: *Chi-square test for independent variables 
Table 2 - Description of the means of instrumental and emotional support of people living with HIV/AIDS, according to the Social Determinants of Health Model, Fortaleza, Ceará, Brazil, 2015

\begin{tabular}{|c|c|c|c|c|c|c|}
\hline \multirow{3}{*}{$\begin{array}{l}\text { Layers of the Social Determinants of } \\
\text { Health Model }\end{array}$} & \multicolumn{6}{|c|}{ Types of Social Support } \\
\hline & \multicolumn{3}{|c|}{ Instrumental } & \multicolumn{3}{|c|}{ Emotional } \\
\hline & Mean & SD & $p$ value & Mean & SD & $p$ value \\
\hline \multicolumn{7}{|l|}{ 1. Individual determinants } \\
\hline \multicolumn{7}{|l|}{ Sex } \\
\hline Male & 3.7 & 0.8 & \multirow{2}{*}{$0.3638^{+}$} & 4.0 & 0.8 & \multirow{2}{*}{0.4330} \\
\hline Female & 3.6 & 0.8 & & 3.8 & 0.9 & \\
\hline \multicolumn{7}{|l|}{ Age group (in years) } \\
\hline$\leq 40$ & 3.7 & 0.7 & $0.5875^{\ddagger}$ & 3.9 & 0.9 & \multirow{2}{*}{0.7818} \\
\hline$>40$ & 3.7 & 1.0 & & 3.9 & 0.9 & \\
\hline \multicolumn{7}{|l|}{ Skin color } \\
\hline Brown & 3.8 & 0.8 & $0.1377^{\ddagger}$ & 3.9 & 0.9 & \multirow[t]{2}{*}{$0.5005^{\ddagger}$} \\
\hline Other & 3.6 & 0.7 & & 3.8 & 0.9 & \\
\hline \multicolumn{7}{|l|}{2 Proximal determinants } \\
\hline \multicolumn{7}{|l|}{ Sexual orientation } \\
\hline Heterosexual & 3.7 & 0.8 & $0.827^{\ddagger}$ & 3.8 & 0.9 & \multirow[t]{2}{*}{$0.1991^{\ddagger}$} \\
\hline Homosexual / Bisexual & 3.7 & 0.8 & & 4.1 & 0.7 & \\
\hline \multicolumn{7}{|l|}{ Physical exercise } \\
\hline Yes & 3.8 & 0.7 & $0.1782^{\ddagger}$ & 4.0 & 0.9 & \multirow[t]{2}{*}{0.2522} \\
\hline No & 3.5 & 0.9 & & 3.8 & 0.9 & \\
\hline \multicolumn{7}{|l|}{ Use of alcohol } \\
\hline Yes & 3.7 & 0.7 & $0.8744^{\ddagger}$ & 4.0 & 0.7 & \multirow[t]{2}{*}{$0.6792^{\ddagger}$} \\
\hline No & 3.6 & 0.8 & & 3.8 & 1.0 & \\
\hline \multicolumn{7}{|l|}{ Use of tobacco } \\
\hline Yes & 3.3 & 1.0 & $0.0576^{\ddagger}$ & 3.6 & 0.8 & $0.0432^{\ddagger}$ \\
\hline No & 3.7 & 0.7 & & 4.0 & 0.8 & \\
\hline Use of illicit drugs & & & & & & \\
\hline Yes & 3.0 & 1.0 & $0.1248^{\ddagger}$ & 3.5 & 0.9 & $0.3332^{\ddagger}$ \\
\hline No & 3.7 & 0.8 & & 3.9 & 0.9 & \\
\hline 3. Influence of social networks & & & & & & \\
\hline Marital Status & & & & & & \\
\hline Single & 3.7 & 0.8 & $0.5722^{\ddagger}$ & 4.0 & 0.8 & $0.3463^{\ddagger}$ \\
\hline Married & 3.7 & 0.8 & & 3.8 & 0.9 & \\
\hline Children & & & & & & \\
\hline Yes & 3.6 & 0.8 & $0.4495^{\ddagger}$ & 4.0 & 0.9 & $0.5064^{\ddagger}$ \\
\hline No & 3.7 & 0.8 & & 3.8 & 0.8 & \\
\hline Number of people in the household & & & & & & \\
\hline 1 & 3.1 & 0.6 & $0.0003^{\ddagger}$ & 4.0 & 0.8 & $0.5877^{\ddagger}$ \\
\hline$\geq 2$ & 3.8 & 0.8 & & 3.9 & 0.9 & \\
\hline Religion & & & & & & \\
\hline Professes & 3.7 & 0.8 & $0.8135^{\ddagger}$ & 3.9 & 0.9 & $0.3477^{\ddagger}$ \\
\hline Does not profess & 3.7 & 0.8 & & 4.1 & 0.7 & \\
\hline 4. Intermediate determinants & & & & & & \\
\hline Household income (Minimum wage) $)^{\S}$ & & & & & & \\
\hline$<3$ & 3.6 & 0.8 & $0.4161^{\ddagger}$ & 3.9 & 0.8 & $0.5882^{\ddagger}$ \\
\hline$\geq 3$ & 3.8 & 0.8 & & 3.9 & 0.9 & \\
\hline Years of education & & & & & & \\
\hline$\leq 9$ & 3.7 & 0.9 & $0.9398^{+}$ & 3.8 & 0.9 & $0.3168^{\ddagger}$ \\
\hline$>9$ & 3.7 & 0.8 & & 3.9 & 0.9 & \\
\hline Employment status & & & & & & \\
\hline Active & 3.8 & 0.8 & $0.1605^{+}$ & 4.0 & 0.9 & $0.2802^{\ddagger}$ \\
\hline Inactive & 3.6 & 0.8 & & 3.8 & 0.8 & \\
\hline
\end{tabular}

Note: SD: standard deviation; †Student's t test; $¥$ Mann-Whitney test; ${ }^{\circledR}$ At the time of the study, the minimum wage was BRL 788, equivalent to USD 251.77.
Table 2 presents a description of the means of instrumental and emotional support for PLWHA, according to the SDHM. It was observed that emotional support is influenced by the use of tobacco $(p=0.0432)$, resulting in smokers receiving less emotional support, whereas patients living alone had the lowest instrumental support ( $p=0.0003$ ).

The main sources of instrumental social support were relatives living outside the household $(66.7 \%)$, spouses/partners $(46.5 \%)$, and family members residing in the same household $(40.6 \%)$. The main sources of emotional support were relatives not residing in the same household $(56.1 \%)$, friends $(55.3 \%)$, and spouses/partners $(50 \%)$. There was a low frequency of support from neighbors, bosses, coworkers and health professionals (Table 3).

Table 3 - Sources of instrumental and emotional social support of people living with HIV/AIDS, Fortaleza, Ceará, Brazil, 2015

\begin{tabular}{lcc}
\hline \multicolumn{1}{c}{ Source of support } & \multicolumn{2}{c}{ Social support } \\
\cline { 2 - 3 } & $\begin{array}{c}\text { Instrumental } \\
\mathbf{n}(\%)\end{array}$ & $\begin{array}{c}\text { Emotional } \\
\mathbf{n}(\%)\end{array}$ \\
\hline Spouse/partner & $53(46.5)$ & $57(50.0)$ \\
$\begin{array}{l}\text { Relative living in } \\
\text { the same household }\end{array}$ & $46(40.6)$ & $44(38.6)$ \\
$\begin{array}{l}\text { Relative not living } \\
\text { in the same household }\end{array}$ & $76(66.7)$ & $64(56.1)$ \\
Friend(s) & $35(30.7)$ & $63(55.3)$ \\
Boss/co-worker & $2(1.8)$ & $4(3.5)$ \\
Neighbor(s) & $5(4.4)$ & $4(3.5)$ \\
Health professionals & $10(8.8)$ & $19(16.7)$ \\
Other & $3(2.6)$ & $3(2.6)$ \\
\hline
\end{tabular}

Note: Participants may have indicated one or more sources of support.

\section{DISCUSSION}

In the social support analysis of PLWHA, from the perspective of the SDHM, it was found that most of the people had satisfactory total social support, which is similar to the results of another study with the same population ${ }^{(7)}$. This finding may be related to characteristics such as good education, active employment status and living with family members - conditions which are associated with better quality of life and more social support ${ }^{(9,12)}$. 
In the context of the SDH, it was observed that PLWHA who did not smoke had satisfactory total social support and greater emotional support, indicating that receipt of social support has an influence on healthy lifestyle habits. As shown in another study, lack of social support can lead PLWHA to use alcohol, tobacco and illicit drugs ${ }^{(13)}$. Furthermore, a study conducted in China found that the likelihood of smoking was significantly higher among PLWHA who had suffered stigmatizing experiences ${ }^{(14)}$, and possibly associated with the absence of social support.

Patients living alone had less instrumental social support compared to individuals living with other people, which may have a negative impact on health care, practical daily activities and financial help. In a study conducted in Iran, marital status and number of family members were significant predictors of social support, based on the fact that higher frequency of contact among members from a support network facilitates relationships and social support ${ }^{(15)}$.

In relation to sources of support, although the nuclear family is considered an important support network for PLWHA to adapt to the disease and treatment ${ }^{(16)}$, it was not reported as the main source of social support in the present study. This result may be due to family members not knowing about the serological status of the PLWHA. The serological diagnosis is often not disclosed to family members, since this condition is still associated with socially reprehensible behaviors, which may lead to discrimination or exclusion from the household ${ }^{(3)}$. In this context, it is important for health professionals to develop care strategies that maintain/increase bonds between patients and their families.

In turn, the significant support from relatives living outside the household and friends may be associated with the fact that support given by family members living in the same household is often considered an obligation, whereas the help of more distant relatives and friends is more voluntary in nature and based on reciprocal gratifications ${ }^{(16)}$. The literature indicates that receiving help from friends and having someone that is concerned about them improves treatment adherence and maintenance by PLWHA ${ }^{(17)}$.

In reference to spouses/partners, the importance of these people as sources of social support was noted. Help from partners is conducive to the well-being and health of PLWHA and enhances their quality of life ${ }^{(9)}$. In addition, support in domestic and operational issues related to treatment is facilitated by geographical proximity among givers and recipients of support $^{(10)}$.

Bosses/co-workers and neighbors were not cited much as sources of social support. Regarding this aspect, even though workers are protected by labor laws in Brazil, they are still vulnerable in labor relationships, due to stigmas and prejudice.
This underscores the need to provide emotional support services in the workplace for PLWHA, as well as expand the social networks supplied by service providers to reduce social isolation ${ }^{(18)}$.

In the present study, there was little mention of health professionals as a source of social support, which may be associated with the limited perception of patients regarding the support offered. Insufficient experience and training of health professionals in caring for PLWHA may be another reason why they were not cited much as sources of support ${ }^{(19)}$.

In this context, it is known that the care of PLWHA by health teams is complex, due to the need to identify vulnerabilities and provide emotional support for those involved. Therefore, it is essential to train professionals to maintain a relationship of empathy and trust with patients, so that they will feel free to express their fears and anxieties ${ }^{(20)}$.

\section{Study limitations}

The study has certain limitations, such as the fact that convenience sampling is a subjective approach, based on the personal decision of the researcher. In the present study, sampling variability was not accurately established. In addition, the cross-sectional design of the study did not permit follow-up of the subjects. Another important limitation was the extensive amount of data collected, which took an average of 60 minutes to collect from each participant, and may have resulted in imprecise information being given. On top of that, the participation of individuals from just one health institution may limit generalization of the results.

Another consideration is that layer 5 was not examined, which refers to the distal determinants involving the economic, cultural and environmental conditions of society, policies in force and globalization, since macrodeterminants are broader aspects that require systematic monitoring to assess their impact.

\section{Contribution to the nursing area}

The investigation of the SDH that predict social support in infectious disease outpatient services enabled the identification of people in vulnerable situations and less likely to receive social support, so that nurses can coordinate the social networks of PLWHA to promote coping with the disease and continued health follow-up.

\section{CONCLUSION}

It was noted, from the SDHM, that total social support was satisfactory. In addition, use of tobacco and the number of people in the household affected social support, such that smokers had less emotional support and people living alone received less instrumental support.

\section{REFERENCES}

1. Brasil. Ministério da Saúde. Secretaria de Vigilância em Saúde. Bol Epidemiol [Internet]. 2017 [cited 2017 Aug 20];48(1). Available from: http://portalarquivos.saude.gov.br/images/pdf/2017/janeiro/05/2016_034-Aids_publicacao.pdf

2. Dimala CA, Atashili J, Mbuagbaw JC, Wilfred A, Monekosso GL. Prevalence of hypertension in HIV/AIDS patients on Highly Active 
Antiretroviral Therapy (HAART) compared with HAART-Naïve patients at the Limbe Regional Hospital, Cameroon. PLoS One [Internet]. 2016 [cited 2017 Aug 20];11(2):1-11. Available from: https://www.ncbi.nlm.nih.gov/pubmed/26862763

3. Van der Heijden I, Abrahams N, Sinclair D. Psychosocial group interventions to improve psychological well-being in adults living with HIV. Cochrane Database Syst Rev [Internet]. 2017 [cited 2017 Aug 20];3:CD010806. Available from: https://www.ncbi.nlm. nih.gov/pubmed/28291302

4. Doku PN, Dotse JE, Mensah KA. Perceived social support disparities among children affected by HIV/AIDS in Ghana: a crosssectional survey. BMC Public Health [Internet]. 2015 [cited 2017 Jan 22];15:1-10. Available from: https://bmcpublichealth. biomedcentral.com/articles/10.1186/s12889-015-1856-5

5. Hao C, Liu H. Actor and partner effects of perceived HIV stigma on social network components among people living with HIV/ AIDS and their caregivers. Glob Health Prom [Internet]. 2015 [cited 2017 Jan 22];22(2):40-52. Available from: https://www.ncbi. nlm.nih.gov/pubmed/25085478

6. Borges DCS, Furino FO, Barbieri MC, Souza ROD, Alvarenga WA, Dupas G. The social network and support of kidney transplanted. Rev Gaucha Enferm [Internet]. 2016 [cited 2017 Jun 20];37(4):e59519. Available from: http://www.scielo.br/pdf/ rgenf/v37n4/en_0102-6933-rgenf-1983-144720160459519.pdf

7. Pedrosa SC, Fiuza MLT, Cunha GH, Reis RK, Gir E, Galvão MTG, et al. Social support for people living with acquired immunodeficiency syndrome. Texto Contexto Enferm [Internet]. 2016 [cited 2017 Jun 20];25(4):e2030015. Available from: http:// www.scielo.br/pdf/tce/v25n4/0104-0707-tce-25-04-2030015.pdf

8. Mendes EV. O cuidado das condições crônicas na atenção primária à saúde: o imperativo da consolidação da estratégia da saúde da família. Brasília: Organização Pan-Americana da Saúde; 2012.

9. Cunha GH, Fiuza MLT, Gir E, Aquino PS, Pinheiro AKB, Galvão MTG. Quality of life of men with AIDS and the model of social determinants of health. Rev Latino-Am Enfermagem [Internet]. 2015;[cited 2017 Jun 20];23(2):183-91. Available from: http:// www.scielo.br/pdf/rlae/v23n2/pt_0104-1169-rlae-23-02-00183.pdf

10. Seidl EMF, Tróccoli BT. Development of a scale for the social support evaluation in HIV/Aids Psic Teor Pesq [Internet]. 2006 [cited 2017 Feb 5];22(3):317-26. Available from: http://www.scielo.br/pdf/ptp/v22n3/08.pdf

11. Seidl EMF, Zannon CMLC, Tróccoli BT. People living with HIV/AIDS: coping, social support and quality of life. Psicol Reflex Crít [Internet]. 2005 [cited 2017 Aug 11];18(2):188-95. Available from: http://bibliobase.sermais.pt:8008/BiblioNET/Upload/ PDF6/004104_Psicol\%20Refl\%20e\%20Cr\%C3\%ADt.pdf

12. Silva LMS, Tavares JSC. The family's role as a support network for people living with HIV/AIDS: a review of Brazilian research into the theme. Ciênc Saúde Colet [Internet]. 2015 [cited 2017 Mar 10];20(4):1109-18. Available from: http://www.scielo.br/pdf/csc/ v20n4/pt_1413-8123-csc-20-04-01109.pdf

13. Sun W, Wu M, Qu P, Lu C, Wang L. Quality of life of people living with HIV/AIDS under the new epidemic characteristics in China and the associated factors. PLoS One [Internet]. 2013 [cited 2017 Apr 27];8(5):e64562. Available from: https://www.ncbi. nlm.nih.gov/pubmed/23741340

14. Zhang C, Li X, Liu Y, Qiao S, Zhang L, Zhou Y, et al. Stigma against people living with HIV/AIDS in China: does the route of infection matter? PLoS One [Internet]. 2016 [cited 2017 May 02];11(3):e0151078.Available from: https://www.ncbi.nlm.nih.gov/ pmc/articles/PMC4794244/

15. Forouzan AS, Shushtari ZJ, Sajjadi H, Salimi Y, Dejman M. Social support network among people living with HIV/AIDS in Iran. AIDS Res Treat [Internet]. 2013 [cited 2017 May 02];2013:1-7. Available from: https://www.hindawi.com/journals/ art/2013/715381/citations/

16. Silveira EAA, Carvalho AMP. Health care support to patients with AIDS: the convoy model and nursing. Rev Esc Enferm USP [Internet]. 2011 [cited 2017 Sep 13];45(3):645-50. Available from: http://www.scielo.br/pdf/reeusp/v45n3/en_v45n3a14.pdf

17. Caixeta CRCB, Morraye MA, Villela WV, Rocha SMM. Social support for people living with aids. Rev Enferm UFPE [Internet]. 2011 [cited 2017 Sep 14];5(8):1920-30. Available from: http://www.revista.ufpe.br/revistaenfermagem/index.php/revista/article/ viewFile/1866/pdf_653

18. Li AT, Wales J, Wonge JP, Owino M, Perreault Y, Miao A, et al. Changing access to mental health care and social support when people living with HIV/AIDS become service providers. AIDS Care [Internet]. 2015 [cited 2017 Jun 20];27(2):176-81. Available from: https://www.ncbi.nlm.nih.gov/pubmed/25069033

19. Vorasane S, Jimba M, Kikuchi K, Yasuoka J, Nanishi K, Durham J, et al. An investigation of stigmatizing attitudes towards people living with HIV/AIDS by doctors and nurses in Vientiane, Lao PDR. BMC Health Serv Res [Internet]. 2017 [cited 2017 Jun 20];17(125). Available from: https:/www.ncbi.nlm.nih.gov/pmc/articles/PMC5301416/

20. Isoldi DMR, Carvalho FPB, Simpson CA. Contextual analysis of nursing assistance to a person with HIV/Aids. Rev Fund Care Online [Internet]. 2017 [cited 2017 Jun 20];9(1):273-78. Available from: http://www.seer.unirio.br/index.php/cuidadofundamental/ article/view/4119/pdf 